\title{
Distribution Systems as a Component of Supply Chain at Hypermarket: Does It Matter?
}

\author{
Matias Andika Yuwono \\ Master Program of Accounting, Widya Mandala Catholic University \\ Jl. Dinoyo 42-44, Surabaya, 60265, Indonesia \\ E-mail: andika.yuwono@gmail.com
}

Received: October 27, 2021 Accepted: November 14, $2021 \quad$ Published: November 17, 2021

doi:10.5296/csbm.v8i2.19124 URL: https://doi.org/10.5296/csbm.v8i2.19124

\begin{abstract}
Distribution is generally a marketing channel for goods that will be determined by companies in distributing or providing related services to agents, intermediaries, wholesalers, and consumers. Distribution channels are very significant in the company's retail activities because this will affect the decisions made by the company managers. The purpose of this study is to produce a study of: distribution channels operated by hypermarts in Sidoarjo. The research is qualitative in nature. The data collection technique is literature study and field study which employs observation and interviews. The sampling technique used is purposive random sampling. The results show that the companies use direct distribution channels because the goods are sold directly to consumers.
\end{abstract}

Keywords: Distribution Channels, Distribution, Hypermarket, Supply Chain

\section{Introduction}

\subsection{Distribution System Is an Important Component in the Supply Chain}

Distribution channel is typically a marketing channel for goods that will be determined by companies in distributing or providing services related to goods to agents, intermediaries, wholesalers, and consumers. Distribution channels are very essential in the activities of retail companies because this will affect the decisions made by company managers. In order to provide a good service to consumers, companies must pay attention to distribution channels by, among others, selecting the distribution channel to be used. If there is an error in choosing a distribution channel, it can hinder the distribution of goods or services to consumers. This needs to be performed by the companies due to the growing demand from consumers for a better and faster service. The competition of companies in providing a good service in quality and the emergence of a variety of products and also the increasing global competition force 
companies to think quickly and precisely of how to reorganize their business. In addition, the competition in the business world is very tight. This condition is based on the shifting habits of people who like manufactured goods, making the flow of money in the buying and selling sector bigger and increasing the number of consumers who shop at modern stores, especially for consumers who live in urban areas (M Taufiq Amir, 2004).

This condition has resulted in the emergence of many modern retailers in Indonesia, especially in the city of Sidoarjo. One form of modern retail is Hypermarket. The existence of hypermarkets has an impact on industrial development in Sidoarjo.

The existence of large retailers has an impact on producers, companies, and governments. From the producer's and company's point of view, it is to increase the marketing capacity of its distributors and related actors. Therefore, entrepreneurs in the retail sector, especially hypermarkets, try to provide products that can meet consumer needs. Moreover, it is hoped that consumers will be loyal to the products. These products are available whenever needed and consumers can find them easily. Products, goods, and services will be meaningless if they are far from the reach of consumers (Arliana Nurbaity Lubis, 2004)

To be able to place goods and services in the right place, with the right quality, in the right quantity, at the right price and at the right time, the right distribution channel is needed. If the company chooses the wrong distribution channel, it will disrupt the smooth flow of goods from the company into the hands of consumers. This happens because consumers do not know the products or if they already know it but do not see them in the market, then consumers will switch to other goods. Therefore, the selection of the right distribution channel will be beneficial in achieving the expected sales targets (Arliana Nurbaity Lubis, 2004).

In addition, producers or small companies with limited financial resources are not able to develop direct selling organizations. Distributors appear to be more effective in wholesaling because of the scale of their operations with retailers and their particular expertise.

Modern factory entrepreneurs prefer to use their funds for business expansion to promotional activities. Retailers selling with large sale volumes prefer to buy various items from a wholesaler rather than buying directly from the individual manufacturers (Henky Lisan Suwarno, 2006).

\subsection{Distribution Channel Concept}

This study emphasizes the concept of distribution channels. The distribution channel concept has an important role in a company in carrying out the obligation to deliver goods at the right time, to the right place and at the right quantity with minimum cost (Buklin, 1966; Adriano Manicoba da Silva, 2008).

Distribution channel theory refers to the approach, namely the economic and behavioral approach. The first is an analysis of channel efficiency, studying issues such as channel design and distribution structure. Furthermore, the sociological orientation focuses on power, cooperation, satisfaction, and conflict in channels. In line with the opinion above, Frazier 
(2009) suggests that the channel in marketing refers to two main concepts.

First, how the channels are organized and centered on the level of channel integration, the trust of the various channels, the intensity of their distribution, and the organizational policies related to centralization, formalization, standardization and oversight (Dwyer and Oh, 1999; John and Weitz, 1988; Fein and Arderson, 1997; Shervani, Frazier and Challagalla, 2007).

Second, how ongoing channel relationships is coordinated with reasonable and very prominent behavior, agreements with certain methods in government channels, including influence rather than contracts, development, and application of power among companies. This issue centers on communication approaches (Frazier, 1983, Anderson and Weitz, 1992, Boyle, Dwyer, Robicheau and Simpson, 1992, Morgan and Hunt, 1994, Kumar, Scheer and Steenkamp, 1995, Lusch and Brown, 1996, in Frazier, 2009).

The structure of distribution channels requires decision making (Rosenbloom, 1999; Lilienet et. al 1992 in Frazier, 2009; Adriano Manicoba da Silva, 2008). The first is a decision that reflects the right type of intermediary such as wholesalers, retailers, franchisees, brokers, salespeople. Both channel intensity includes how many intermediaries and levels in the channel structure. The second is channel, channel intensity, which is a key element in the distribution strategy (Coughlan et al,, 2001; Lilien, et al.. 1992; Adriano Manicoba da Silva, 2008) and sometimes the rules in the distribution channel structure have an influence on the type of intermediary, the scope of the market, and the type of distribution (direct or indirect).

Furthermore, channels in marketing are related to physical distribution and are essential in management. In marketing literature, common acceptable topics cover operations management, logistics, transportation, purchasing, and information technology, with a common focus including how to order goods and deliver effectively to channel members and end users (consumers). Among the main things include inventory management, numbering, placement, and design of warehouse or distribution channels, use of technology to assist the ordering process, shipping rules for consumers, and customer payment methods (Innis and Lalode, 1994; Emerson and Grimm, 1996; Giannakis and Groom, 2004; Giunipero, Hooker, Joseph-Matthews, Yoo and Brudvig, 2008 in Frazier, 2009).

This research focuses on combining two approaches, namely economic and behavioral approaches. The first is an analysis of channel efficiency, studying issues such as channel design and structure. The second - sociological orientation - focuses on consumers. Based on this approach, the researcher is interested in raising the topic of company strategies associated to distribution channels implemented by hypermarkets in Sidoarjo. Keeping in mind the two approaches, the researcher is interested in raising the topic of company strategies related to distribution channels implemented by hypermarkets in Sidoarjo.

The results of this study are expected to provide input in the form of ideas or thoughts on hypermarkets so that they can establish implementation of the right distribution system strategy in the future. In the long run it is expected that they can increase sales results and provide big profits for business or hypermarkets owners. 


\section{Method}

The approach used in this study was a qualitative approach. The research was conducted inductively to obtain comprehensive or holistic and in-depth data. It is in line with the objectives of a qualitative research, namely to build a causal explanation and to try to explain the decline in the growth of hypermarkets in Sidoarjo and at the same time to reveal its meaning in terms of distribution channels. In addition, the design of this research was open, meaning that within a certain period of time, important aspects were found and included in the research even though they were not expected.

This qualitative research was carried out using a case study approach. A case study is an empirical inquiry that investigates a phenomenon in a real-life context (Yin, 2005). This study investigated the phenomenon of the decline in the number of hypermarkets in Sidoarjo from the point of view of the distribution system.

The data sources of this research consist of two elements as described below:

a. Primary data sources which were obtained by interviewing Hypermarket managers.

b. Secondary data sources which contained the development of Hypermarkets in the Government of Sidoarjo and the Office of Industry and Trade of Sidoarjo, and the product characteristics coming from hypermarkets.

Data collection techniques include the followings:

Documentation Study where the researcher collected the data using literature both from books and journals. The data were collected by observing and recording directly on the object under study. The observations were made by witnessing activities at the chosen Hypermarket. This activity was carried out at 1 p.m. This was done because of the large number of visitors who came to the sites. Observation time was about 40 to 60 minutes. Only three sites were opted because the place in question has a lot of visitors and was very conducive to observation. In addition, the mobility of visitors was very high.

In-depth interviews through question and answer and dialogue with interested parties/authorities from related institutions/companies to get an overview of the company. The interview employed in this research was direct interview technique. The main information was obtained from hypermarket managers (Transmart, Hypermart, Superindo), producers and consumers/customers who were shopping. The interviews were conducted with three sources. First, interviews with consumers regarding: complaints or problems about the products sold by the hypermarkets. Five people were engaged per hypermarket. Interview time was about 20 minutes. Second, interviews with hypermarket managers was performed by asking questions about the products and distribution strategies they had implemented and how to deal with the things that consumers complained about. The duration of the interview was about 1 to 2 hours. Third, interviews with the manufacturers were carried out to make sure about their involvement in the respective hypermarkets. 


\section{Macrothink}

Data analysis in this study followed the quantitative data analysis model of Miles and Huberman. According to Miles and Hubermen quoted by Sugiono (2011), the analysis can be done in three steps as follows:

\section{Data Reduction}

Data reduction means summarizing, choosing the main things, focusing on the important things, looking for themes and patterns. Thus the reduced data will provide a clearer picture and make it easier for the researcher to conduct further data collection when needed.

\section{Data Presentation}

After the data is reduced, the next step is to present the data to make it easier to understand what happens and to plan further work based on what has been understood. In a qualitative research, data presentation can be done in the form of brief descriptions, charts, relationships between categories, flowcharts, and the like. In this case, a typical one which is used to present data in a qualitative research is a narrative text.

\section{Conclusive drawing/verification (drawing conclusions/verification)}

The initial conclusions put forward are still temporary and will change if no strong supporting evidence is found at an early stage but supported by valid and consistent evidence when the researcher returns to the field to collect data for credible conclusions.

In line with the explanation above, conclusions in a qualitative research may (or may not) be able to answer the problems formulated from the beginning because as stated previously the problem formulation in a qualitative research is temporary; it becomes obvious when researcher is in the field.

Data findings in a qualitative research are declared valid if there is no difference between what is reported by the researcher and what actually happens to the object under study. For this reason, it is necessary to test the truth value (credibility test) of the data obtained. Testing the credibility of research data can be carried out by a triangulation and discussion with the research team.

\section{Triangulation}

Testing the credibility of research data involves triangulation techniques and triangulation of data sources. Triangulation technique means asking the same thing with different techniques. This can be performed by means of interviews, observation, and documentation. In this research, the triangulation of data sources was done by asking the same thing to the following different sources: Hypermarket managers and Hypermarket consumers.

\section{Discussion with the research team}

The results of this study were discussed with the research team. Through this discussion, the researcher received many inputs and questions regarding the data obtained. Thus the data will be complete and more credible. 


\section{Results and Discussion}

In conducting distribution channels, it is necessary to pay attention to these two elements:

First, it's about Facilities. Facilities related to the location and capacity of the seller. The locations chosen by hypermarkets tend to be closer to offices and housing. Hypermartket Lippo Plaza Sidoarjo and Hypermartket Transmart are two examples. This location determination aims to provide excellent service to consumers or for the sake of sales capacity. The tasks must be done by a salesman for 8-10 hours every working day. This relates to serving the target consumers, handling consumer/customer complaints such as damaged goods purchased, product guarantees, inappropriate price discounts and so on.

Second, it's about Stock. Hypermarkets adhere to a make to stock system to meet uncertain demand and plan capacity requirements. This happens because the goods stored depend on the sale of goods given to consumers.

The principle held in inventory management is conformity to needs. Compliance with needs is based on the estimated number of orders within a certain time period. The number of items ordered is only based on how many items are needed and not on the request of the manufacturers/suppliers. Hypermarkets emphasize daily necessities such as cooking oil, vegetables, fruit, margarine. Hypermarket is a form of supermarket that has inventory, which is more than 25,000 items which include food products, hardware, sports equipment, furniture, household equipment, electronics, and so on.

Accountability. Any number of goods ordered will affect the value of the stock of goods. This usually happens when the goods that are about to expire are usually sold at a very large discount of up to $50 \%$ to $70 \%$. But if the goods are new, the discount is only $20 \%$.

As of inventory, inventory control is carried out. The goal is to ensure every transaction or process point in the process flow takes place correctly. This activity is also carried out at hypermarkets inculding Hypermart, Transmart, and Superindo. Every day checks are done by looking at the initial data and the latest sales data and also by sorting the categories of goods according to the provisions. This is done to avoid leaks or deviations from procedures that will result in discrepancies between the amount and value of inventory.

Usually, inventory is performed when the shop is closed. Special items that do not have a long shelf life such as vegetables and fruits or wet food will be sorted out from the items that will be served on the next day. However, before operating the store the next day, it is re-checked.

Subscription requests are met with standard products, such as cooking oil, instant noodles, margarine, laundry soap. These primarily include products that are consumed repeatedly or daily by consumers.

The main problems in carrying out operations are forecasting, inventory management, and capacity planning. This happens because the demand is uncertain. Usually the goods demanded depend on the existing inventory or depending on sales or depending on the unpredictable tastes of consumers. 
Transportation. The purpose of transportation/shipping planning is of three things. First, it is to achieve the delivery target of the distributed products. Second, it reduces the problem of not focusing on delivery issues which will be very detrimental to product distribution. Third, it is to prepare the shipping department to be ready to send products in an emergency. Usually, hypermarkets integrate transportation cost which is already included in the cost or price of the goods.

Communication relates to order processing systems, billing systems and demand forecasting systems. Hypermarkets open delivery and billing when goods are purchased on credit. In addition to serving consumers, hypermarkets cooperate with banks in supporting the payment of goods. Some cooperating banks include BNI, Mandiri, BCA and so on.

Implementation of Distribution Channels at hypermarkets in Sidoarjo.

The channels that many producers choose are Producers - Wholesalers - Consumers. These are called traditional distribution channels. Distribution channel is an important characteristic in a process to get products from consumers. Distribution channels can be centralized and decentralized. Centralized channels are committed to agents who act as intermediaries between producers and consumers. Decentralized ones relate to consumers and agents in this case intermediaries who can buy directly from producers.

Hypermarkets adopt a centralized system, where retail is more of an intermediary between producers and consumers. They have a written agreement in terms of determining the price of the product to be sold to consumers.

Hypermarkets prevalently cover an area of more than 18,000 square meters with a combination of $60-70 \%$ food products and $30-40 \%$ general products. The highlight is the large display and minimal handling by shop assistants, with discounts given to customers who are willing to take heavy household appliances and furniture out of the shop. Hypermarkets also provide cafeterias such as A\&W, The Tongji, Shoe Stores, and Clothing Stores.

Hypermarkets do Trading Term. Trading terms are carried out between companies and producers to deal with prices, especially product pricing, discounts and so on

Goods marketing. Items sold at hypermarkets vary - about 25,000 items. Producers who cooperate are numerous and have well-known brands. The food category belongs to among others Garuda Food, Indofood, and Nestle. For the household category, the producers involved are Unilever, $\mathrm{P}$ and $\mathrm{G}$ and so on. This is done because most consumers really like old brands. One way to market their goods is by issuing a catalog.

Apart from that, hypermarkets produce private labels, namely products that are issued under the name of the store and in collaboration with other suppliers. Hypermart, Transmart, and Superindo issue private labels such as cooking oil, tissue, and hand soap.

Price of goods. Prices provide satisfaction to consumers. The purpose of setting prices is to get a reasonable profit that allows the companies to be able to run its business sustainably. This is done to attract shopping interest, set a target market, determine margins, build an 
image and win the competition

In determining the price of goods, hypermarkets put pressure on producers/suppliers for goods to be sold. The goods can be increased first by wholesalers, in this case the hypermarkets spend $20 \%$ of the existing value. They get a profit of about $20 \%$ of the products issued by the suppliers or producers. As an illustration, the goods to be sold are counted as follows Rp. 20,000 or $20 \%$ is owned by hypermarkets and $80 \%$ is owned by suppliers.

If the goods are in the form of consignment, they will usually be exchanged if they are not sold. The strategy carried out regarding the price of goods will change depending on the resilience of the goods. Hypermarkets will usually give a big discount of around $50 \%$ if the goods offered will expire in about 3 to 5 months. This is to spend the remaining items in the warehouse. They will immediately release the goods that are in the inventory or supplier. Goods that are not lasting long will be the priority to be sold. Apart from that, when the companies are going to do a promotion, usually the price is negotiated with the suppliers. Or usually, the companies have a schedule of when the goods will be given a discount.

Exchange of goods. Hypermarkets can replace wilted items such as vegetables every day. This is done to satisfy their consumers. Usually there is an exchange of goods for a store warranty of about 1 day while the warranty from the factories or the manufacturers is about 1 week or more. For goods that are easily wilted or perishable, usually hypermarkets will package them into cooked food or wrap them in transparent plastic. This is not to deceive customers or consumers about the goods to be purchased, but it is intended to avoid company losses.

In introducing a new item, a product sample is usually given. The sample is usually attached to the product such as shampoo, drink, or soap products.

In relation to producers/suppliers, hypermarkets implement a mix margin strategy, cross subsidies between items/categories. They get extra discounts for buying large buying power and interest margins in addition to making sales incentives (rebates) and marketing income (fees). Although the selling price level is relatively low, the sales margin is maintained as expected (around 10-12\%), due to the relatively low real purchase price. In price competition, hypermarkets will push the selling price to a level below the market/average price. The increase in the total or bulk price will then have an impact on the increase in the average purchase price of consumers.

Thus, price competition between hypermarkets only has temporary impact on price declines. However, the selling margin is always at an adequate level because hypermarkets get regular purchase discounts which are generally around 1-2\% larger than ordinary supermarkets because of the relatively large average purchase volume so that they are equated with wholesalers. In addition, they also get a total additional discounted value that is greater than the scheduled promotional activities. The discount will directly affect the calculation of the selling price. So naturally, even with the same selling margin, the average selling price of hypermarket goods could be much lower. (Asep ST Sudjana, 2009).

Apart from that, Hypermarkets apply a Listing Fee, which is a placement of goods in a 
leading or outstanding site. Usually, items served in the front row near the cashier or front aisle must pay the placement fee. The suppliers have to give around One Million Rupiah or Two Million Five Hundred Rupiah per item or more according to the initial agreement. This is usually done on a rotating basis.

To increase sales, hypermarkets usually provide stimulation with coupon promotions. This is related to cooperation with manufacturers. For example, goods buying for One Hundred Thousand Rupiah gets one point, and can be exchanged for certain items with a predetermined time limit. This activity is carried out to increase sales. For example, in introducing a new product, a sample of the product is usually given. Samples are usually attached to the product such as shampoo, drink, or soap products.

According to the hypermarket managers, discounting is done if the product has passed its lasting period from 6 months to 12 months or the retention period of goods is over. Food and beverages might have the discount is $50 \%$ to $70 \%$. Products with a period of 3 to 6 months are offered at a discount of $10 \%$ to $20 \%$ or special prices for introducing new products.

Hypermarkets push the selling price at a level below the market price or below the average. However, the sales margin is at an adequate level because hypermarkets get regular purchase discounts which are generally around 1-2\% larger than regular supermarkets due to the relatively large average purchase volume equated with wholesale. In addition, they also get a total additional discounted value that is greater than the scheduled promotional activities. Giving discounts directly affects the determination of the selling price. The average selling price of hypermarkets can therefore be much lower than others.

The period of time for giving discounts is usually scheduled to coincide with special events such as birthdays, or new years or other terms related to ordinary days (Monday and Tuesday or Thursday, Friday, Saturday). The price discount is divided into two parts according to the hypermarket managers' decision. The first relates to price discounts originating from national headquarters. The second decision depends on the respective stores which need to consider goods especially expired items.

Discounts are offered by hypermarkets in the form of shopping vouchers. Vouchers are given in collaboration with Hypermart and the suppliers. Meanwhile, Transmart and Superindo rarely give vouchers. Hypermart provides vouchers only on weekends or during special events such as birthdays or certain events. According to retail experts, Hypermart vouchers are carried out to increase sales.

According to the managers, gifts are usually in the form of available goods or special goods offered by the suppliers. Some gifts are in the form of a beautiful wallet after toothpaste purchase and a glass after calcium milk product purchase. Gifts given by hypermarkets depend on the suppliers.

The consumers are the object of the hypermarkets. Satisfaction shown by the consumers will provide advantages or disadvantages for the companies. Profits and loyalty to the goods are obtained if the consumers are satisfied. But the loss will appear if the consumers are very disappointed with the service, the goods are not in accordance with their wishes. They will 
consequently not come back to shop. Therefore Hypermarkets are very concerned about the existence of their consumers.

Characteristics of consumers/customers can influence the determining of distribution channel. In the consumer segment, it can be seen from various angles. The geographical segments might relate to countries, cities and so on. The demographic segment might cover age, family, lifestyle, gender, income, occupation, education, and social class (Kotler and Keller, 2012). In this study, demographic factors tend to be due to this aspect, influencing the determining of the distribution channel.

Furthermore, based on demographic factors, it can be described as follows. Consumers of hypermarkets in Sidoarjo are more dominated by civil servants, state-owned enterprises and the private sector and entrepreneurs. This indicates that the hypermarket consumers are dominated by working people. They make purchases when they get home from work around 17.00 to 20.00. But sometimes they make purchases during recess. Usually, they buy snacks or they buy heavy food. This is also due to the number of workers because the location of the hypermarkets is close to offices. This applies to Lippo Plaza Sidoarjo Hypermarket.

Consumers who shop at hypermarkets are dominated by those under 35 years of age. This indicates that hypermarkets target a productive age and are an outlet favored by young people. Usually, they come to shop for food and soft drinks or monthly shopping. This applies to Lippo Plaza Sidoarjo Hypermarket and Transmart Sidoarjo because the place is integrated with shopping centers (malls) and entertainment places such as cinemas. Most young consumers buy food or soft drinks when they are going to watch a movie.

Hypermarket enthusiasts (Hypermart, Transmart, Superindo) are dominated by women. Most women flock to the hypermarkets for shopping and socializing. This is in accordance with the purpose of hypermarkets namely providing basic necessities which are usually bought by women. This indicates that hypermarkets are favored by women who are identical to shopping activities. While most of the men usually come to the hypermarkets for lunch during breaks or gathering with family on weekends. But sometimes men make the purchases they need on the same day. Or they usually make purchases during break time. They usually eat the food available at the hypermarkets.

Hypermarket income is identical to middle and lower middle-class consumers. Consumers who make purchases at the hypermarkets have an average income of under Two Million Rupiah This means that the average Hypermarket consumer in Sidoarjo is the middle class and the lower middle class.

They usually shop for daily necessities or for resale. Usually, consumers shop at the hypermarkets at different time. High school students and university students usually do so around 13.00 to $15.00 \mathrm{WIB}$. Meanwhile the employees do this shopping activity when they go home from the office at around 17.00 to 20.00 WIB.

Apart from demographic factors, the number of customers is also considered in determining distribution channel. This statement can be explained as follows: 


\section{Ml Macrothink}

It can be seen that the number of visits made by customers is dominant on weekends, namely on Fridays, Saturdays and Sundays. This indicates that hypermarkets are a place for shopping and recreation. In this regard, the number of customer visits to the store per day is dominated by weekends - around 2000 visitors compared to weekdays ranging from 1200 to 1500 people.

The time of consumers who visit shopping centers, especially hypermarkets in Sidoarjo, is based on several reasons. First, it is more likely to be done on weekends. Second, it is done when there are items that are needed. Third, the visit is after receiving salary/wages. Fourth, when it is time to meet friends. The table below summarizes the findings:

Table 1. Period of Purchasing at Hypermarkets

\begin{tabular}{|l|c|}
\hline \multicolumn{1}{|c|}{ Visit to Hypermartkets } & Percentage \\
\hline On weekends & $35 \%$ \\
\hline When in need of goods & $30 \%$ \\
\hline When salary is in hand & $20 \%$ \\
\hline When having a meeting with friends or colleagues & $12 \%$ \\
\hline Others & $3 \%$ \\
\hline
\end{tabular}

It is found in this study that consumers prefer the activities around 13.00 to 20.00 . This activity is carried out after they finish doing their homework, office, school, and other activities. This can be seen as follows:

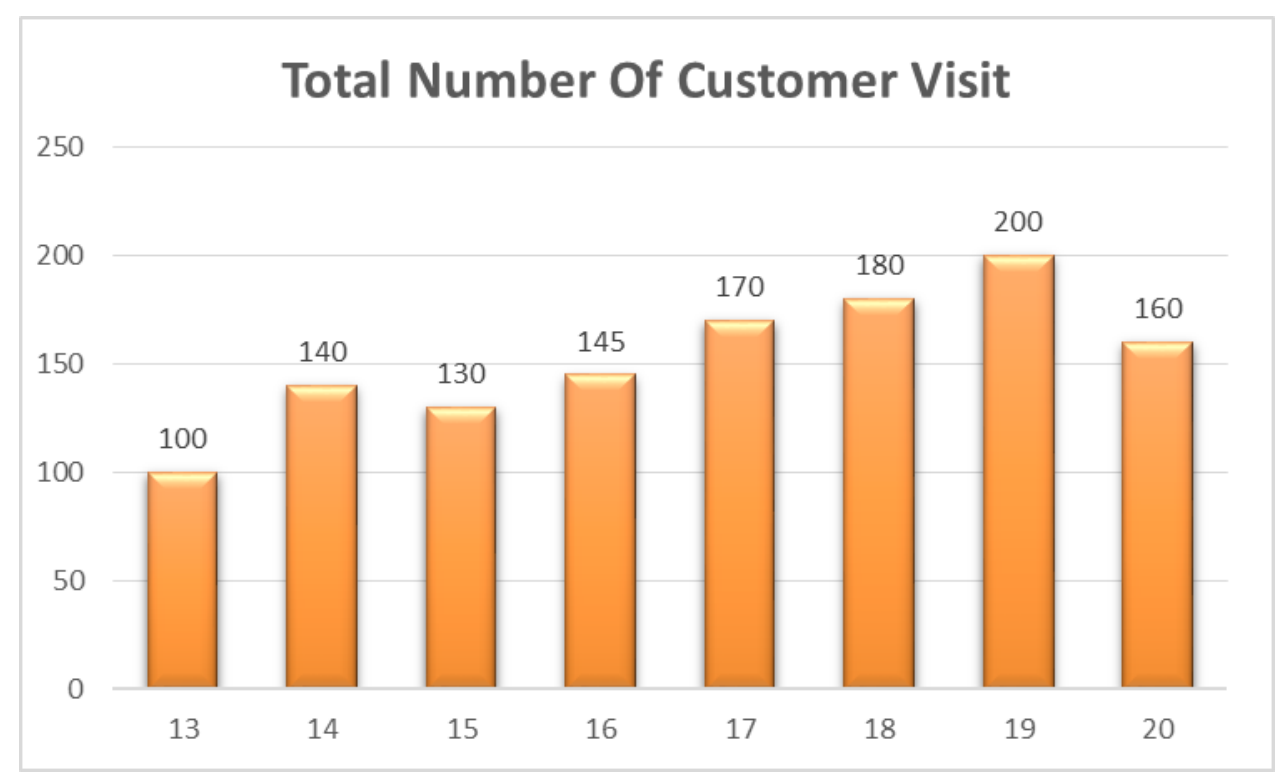

Figure 1. Average Visit Time of Hypermarket Consumers

Consumer characteristics seen from consumer behavior can affect the design of distribution channels. This is related to the habit of shopping habits. Consumer behavior leads to impulsive decisions. Impulse buying emphasizes someone's interest in a product offered by a hypermarket without considering whether the items are really needed or not. In other words, 
it is more based on emotional factors. According to Dittmar, Beattie and Friese (1995, in Tremblay, 2005), impulse buying activities are carried out for about 50\%. Impulse buying activities carried out by consumers at hypermarkets in Sidoarjo ranged from $40 \%$ on weekdays and $55 \%$ on holidays or weekends.

Impulse buying behavior is more likely to be done by teenagers and housewives. It is more dominated by women. They do that because they see an attractive layout and like shopping activities. They spend a lot of shopping at hypermarkets and it takes more than 30-45 minutes. The opposite of impulse buying or planned buying is done by workers, traders and it tends to be done by men compared to women. The reason is that men do not really like shopping activities that often take long time.

\section{Conclusion}

Distribution channel is important in retail activities of especially hypermarkets. Distribution channel is a structure that describes the alternative channels chosen and that also describes the marketing situation of companies. In this case, hypermarkets conduct distribution channel by referring to the concept of producers, wholesalers, and consumers.

In carrying out distribution channel activities, hypermarkets carry out Trading Terms, which are agreements made by hypermarkets and producers/suppliers. This collaboration relates to the marketing of products, pricing, and promotion of the goods issued.

Hypermarkets in Sidoarjo implement a short distribution system that directly serves immediate customers. This can be seen from the types of retail goods sold by hypermarkets in Sidoarjo. In order to increase distribution to customers, hypermarkets carry out intensive collaboration with customers such as providing discounts and giving shopping vouchers to stimulate consumer purchasing power.

\section{References}

A. Edward, \& Madugu, A. (2011). Marketing and Distribution Channel of Processed Fish in Adamawa State. Nigeria: Global Journal of Management and Business Research.

Amir, M. (2004). Manajemen Retail. Jakarta: Penerbit PPM.

Bucklin LP. (1962). Retail Strategy and the Classification of Consumer Goods. Journal of Marketing. https://doi.org/10.2307/1248582

Bucklin LP. (1966). Theory of Distribution Channel Structure. Berkeley. CA.: IBER. Special Publications.

Coughlan A. Anderson. E. Stern, L. E.-A. (2001). A Marketing Channels. New York: Prentice Hall.

Fauzi, I., Satria, \& Adhie, F. (2010). Marsindonesia. Jakarta.

Fraizer GL. Lassar, W. (1996). Determinants of Distribution Intensity. Journal of Marketing, 39-51. https://doi.org/10.1177/002224299606000405 


\section{Macrothink}

Case Studies in Business and Management ISSN 2333-3324 2021, Vol. 8, No. 2

Fraizer, G. L. (2009). Physical Distribution And Channel Management A Knowledge And Capabilities Perspective. https://doi.org/10.1111/j.1745-493X.2009.03161.x

Kotler, P., \& Gary Armstrong. (2006). Principles of Marketing. America: Pearson Prentice Hall.

Kotler, P., \& Kevin Lane Keller. (2012). Marketing Management. America: Pearson Prentice Hall.

Lilien, Kotler, \& Morthy K. (1992). Marketing Models. New Jersey: Prentice Hall.

Lubis, A. (2004). Peranan Saluran Distribusi Dalam Pemasaran Produk dan Jasa (Vols. 1-2). Sumatera Utara.

Rangan.VK.Menezes, M. (1992). Channel Selection for New Industrial Products ; A Framework, Method and Application. Journal of Marketing, 69-82. https://doi.org/10.1177/002224299205600305

Sapu Jagat. (2010). Menelisik Geliat Bisnis Ritel Modern. Jakarta.

Silva, A. M. (2008). Distribution Channel Structure. Revela Journal, 1-3.

Stern, L. W. (1980). Distribution Channels as Political Economies; A Framework for Comparative. Journal of Marketing, 52-64. https://doi.org/10.1177/002224298004400306

Sugiono. (2011). Metode Penelitian Kuantitatif Kualitatif dan $R \& D$. Bandung: Peneribit Alfabeta.

Sujana, A. (2012). Manajemen Minimarket. Jakarta: RaihAsaSukses.

Sujana, A. S. (2012). Menyingkap Rahasia Sukses Global Retailer. Jakarta: Gramedia.

Suwarno, H. L. (2006). Sembilan Fungsi Saluran Distribusi : Kunci Pelaksanaan Kegiatan Distribusi Yang Efektif. Jurnal Manajemen, 79.

Syntia Atas, S. (2012). Pemasaran Internasional. Jakarta.

Tremblay, A. J. (2005). Impulse Buying Behavior: Impulse Buying Behavior Among College Student In The Borderlands. United States: The University of Texas at ElPaso.

Yin, R. (2005). Studi Kasus : Desain dan Metode. Jakarta: PT. Raja Grafindo Persada.

\section{Copyrights}

Copyright for this article is retained by the author(s), with first publication rights granted to the journal.

This is an open-access article distributed under the terms and conditions of the Creative Commons Attribution license (http://creativecommons.org/licenses/by/4.0/). 